Volume 9, No.1.3, 2020

International Journal of Advanced Trends in Computer Science and Engineering

Available Online at http://www.warse.org/IJATCSE/static/pdf/file/ijatcse6591.32020.pdf

https://doi.org/10.30534/ijatcse/2020/6591.32020

\title{
A Flexible Learning Framework Implementing Asynchronous Course Delivery for Philippine Local Colleges and Universities
}

\author{
Mideth B. Abisado, Maricris G. Unico, Danny G. Umoso, Filipina E. Manuel, Shalini S. Barroso \\ Pamantasan ng Cabuyao, Philippines, mideth.b.abisado@gmail.com \\ Pamantasan ng Cabuyao, Philippines, krysunico.pm@gmail.com \\ Pamantasan ng Cabuyao, Philippines, danny.g.umoso@gmail.com \\ Pamantasan ng Cabuyao, Philippines, femanue1527@gmail.com \\ Pamantasan ng Cabuyao, Philippines, shalinibarroso1106@gmail.com
}

\begin{abstract}
The Corona Virus 19 (COVID 19) pandemic has brought challenges and opportunities in the world and the Philippine educational system. While there are universities that are doing online learning in the past decades, over 100 local universities and colleges are left with traditional instruction, face-to-face learning sessions. The traditional universities have no choice but to become adaptive to the "new normal" once declared by the World Health Organization. Philippine data on the effect of pandemic suggest that the student populace are prone to carry the virus through interaction and traveling to and from the schools. Classes cannot be delivered in traditional ways anymore, to mitigate the spread of the virus, until a vaccine is available. This paper provides a framework for local universities and colleges in implementing flexible learning procedures. The asynchronous course delivery consists of the design of outcomes-based teaching and learning plan, course materials, scheduled on-line and face-to-face meetings, technology, and center for technology education.
\end{abstract}

Key words: COVID-19, flexible learning, online learning, e-learning, asynchronous learning, local university

\section{INTRODUCTION}

In March 2020, Philippine President Duterte put the entire Luzon region in the Philippines under "enhanced community quarantine" (ECQ), which is a complete lockdown, limiting population movement but with exceptions, in response to the the coronavirus disease pandemic in the country in 2019 (COVID-19). Additional limits on lockout forced the immediate closing of non-essential stores and businesses. The Philippine Commission on Higher Education (CHED) advised the Higher Education Institutions (HEIs) to start adopting flexible learning modalities to ensure safety of the Filipino learners against being infected with the virus. The oppressed members of the student population in the
Philippines lack access to a secure Internet connection at all times. This is all the Local Universities and Colleges (LUC) struggle to design flexible learning methods to mitigate virus spread. There should be no stopping schooling. The Pamantasan ng Cabuyao (PNC), a local university without online modalities for 16 years, is faced with an opportunity to provide flexible learning modalities to its students while taking into consideration accessibility[1]. Flexible learning in earlier definitions refers to distance education programs[2], however, in this paper, flexible learning refers to a learning modality apart from the traditional face-to-face in campus and in classroom. Flexible learning can be full-online, blended learning, flipped classroom, and distance learning. This paper presents the design of a flexible learning framework implementing asynchronous course delivery for LUCs. This study uses faculty and student data of the Pamantasan ng Cabuyao as its basis for the design of the framework.

\section{RELATED STUDIES}

\subsection{Equipping the University}

The University must have procedures in place for implementation of a flexible learning. CHED COVID Advisory 6[3], advices HEIs to "conduct an inventory of all their constituents and categorize those who are coming from localities with and without COVID-19 positive cases. HEIs shall put up mechanisms to monitor the health of its students, faculty and staff, especially those coming from COVID-19 positive areas, and ensure that they get appropriate health care if they are ill". In cases that PNC may not be able to comply due to the expected student population of more than 3,000, it is proposed to provide the following: Online (off-campus) Enrollment System and Online payment option for paying students.

The LUC may involve the Local Government Unit through its Barangay Units to help facilitate enrollment of students without Internet access, in the form of delivering enrollment 
Mideth B. Abisado et al., International Journal of Advanced Trends in Computer Science and Engineering, 9(1.3), 2020,413 - 421

forms, or as transport service, and distribution and collection of learning materials to enrolled students.

\subsection{Learning Management System}

The standard classroom, paper textbooks, and paper handouts are no longer the only way to teach and educate students. The development of information and information technologies has provided an opportunity for their direct use in the training process[4]. Learning Management Systems (LMS) are used to provide a safe, reliable, and flexible learning environment[5][6][7]. The LUC has the option to use proprietary or free LMS, among the recommended choices are as follows: Moodle, Microsoft Teams, Google Classroom, Edmodo, Blackboard, Canvas by Instructure, NEO LMS. LMS must be adaptive to the needs of the teaching and learning process[8][9]. The following features in the selection of the LMS should be considered, as reflected in Table $1[10][4][11][6]$.

Table 1: Learning Management System Features

\begin{tabular}{|c|c|}
\hline LMS Feature & Functions \\
\hline Learning Skills Tools & $\begin{array}{l}\text { a. Creative activities and learning } \\
\text { tools or Shareable Content Object } \\
\text { Reference Model (SCORM) } \\
\text { compliant } \\
\text { b. Lectures as web pages, } \\
\text { documents, presentations, videos, } \\
\text { etc. } \\
\text { c. Examples and tasks, like web } \\
\text { pages, documents, presentations, } \\
\text { videos, etc. } \\
\text { d. Assignments and exercises } \\
\text { as web pages, documents, } \\
\text { quizzes } \\
\text { e. Gamification } \\
\text { f. Evaluation }\end{array}$ \\
\hline $\begin{array}{l}\text { Communication } \\
\text { Tools }\end{array}$ & $\begin{array}{l}\text { Allows interaction between lecturers } \\
\text { and students } \\
\text { a. Chat } \\
\text { b. Forums } \\
\text { c. Email messages }\end{array}$ \\
\hline Productivity & $\begin{array}{l}\text { The software functionalities } \\
\text { provided by LMS systems o } \\
\text { Uploading/downloading various } \\
\text { documents types } \\
\text { a. Add, edit, delete data for students } \\
\text { b. Analysis of students' } \\
\text { achievements and outcomes } \\
\text { c. Multiplatform support } \\
\text { d. Security and protection of users' } \\
\text { data } \\
\text { e. Creating a data backup } \\
\text { f. Need for a system administrator } \\
\text { that can manage all the user roles } \\
\text { in the LMS } \\
\text { g. Web-based technology of } \\
\text { hoftware development } \\
\text { h. Need for installation } \\
\text { i. Self-Registration } \\
\text { j. Maintaining class records and } \\
\text { individual student statistics }\end{array}$ \\
\hline
\end{tabular}

The following table shows LMS that are adopted by different HEIs in the country, as summarized in Table 2.

Table 2: LMS Adopted by HEIs

\begin{tabular}{|c|c|c|}
\hline $\begin{array}{c}\text { Learning } \\
\text { Management System }\end{array}$ & $\begin{array}{l}\text { Users } \\
\text { Accdg. To } \\
\text { the LMS } \\
\text { Website }\end{array}$ & $\begin{array}{c}\text { Used by Philippine } \\
\text { HEI }\end{array}$ \\
\hline $\begin{array}{l}\text { BlackBoard } \\
\text { (https://www.blackbo } \\
\text { ard.com) }\end{array}$ & $25,000,000$ & $\begin{array}{l}\text { Mapua University } \\
\text { University of Santo } \\
\text { Tomas }\end{array}$ \\
\hline Microsoft Teams & $44,000,000$ & $\begin{array}{l}\text { St. Paul University } \\
\text { National University }\end{array}$ \\
\hline $\begin{array}{l}\text { Edmodo } \\
\text { (https://www.edmodo. } \\
\text { com/) }\end{array}$ & $58,000,000$ & \\
\hline $\begin{array}{l}\text { Instructure (Canvas) } \\
\text { (https://www.instructu } \\
\text { re.com/) }\end{array}$ & $20,000,000$ & $\begin{array}{l}\text { All Far Eastern } \\
\text { University } \\
\text { University of the East } \\
\text { Technological Institute } \\
\text { of the Philippines } \\
\text { Jose Rizal University } \\
\text { Centro Escolar } \\
\text { University } \\
\text { Baliuag University }\end{array}$ \\
\hline $\begin{array}{l}\text { Moodle } \\
\text { (https://moodle.com/) }\end{array}$ & $\begin{array}{l}142,106,52 \\
8\end{array}$ & $\begin{array}{l}\text { Unibersidad de Manila } \\
\text { All Ateneo Schools } \\
\text { University of the } \\
\text { Philippines } \\
\text { Bicol University }\end{array}$ \\
\hline Google Classroom & $\begin{array}{l}120,000,00 \\
0\end{array}$ & $\begin{array}{l}\text { Don Mariano Marcos } \\
\text { Memorial } \\
\text { University } \\
\text { Western State } \\
\text { State University } \\
\text { Philippine Women's } \\
\text { University }\end{array}$ \\
\hline
\end{tabular}

This paper recommends Moodle as the standard LMS to be adopted. A Faculty Capability Training should be conducted to equip faculty on the use and features of Moodle. To have effective implementation of the LMS, the University should also fill the personnel required for an administration and maintenance of the Learning Management System (LMS Administrator) subject to the approval of the Board of Regents.

\section{METHODS}

This study conducted surveys and interviews towards the design of an asynchronous course delivery framework for LUCs. The survey focused on Internet Accessibility and their Digital Learning Readiness. The Internet Accessibility Survey (IAS) comprised of questions measuring availability of access to the Internet and internet devices of the PNC faculty and students. The IAS measures the following demographic and questions:
a. Barangay
b. City/Municipality 
Mideth B. Abisado et al., International Journal of Advanced Trends in Computer Science and Engineering, 9(1.3), 2020,413 - 421

c. Availability of Internet access at home

d. Type of internet connection

e. Internet service provider

f. Willingness to purchase internet device

g. Weekly expense on network data

h. Gadgets owned and use at home

i. Facilities for online learning

j. Alternative places where computer work is done

k. Given the challenges and limitations because of COVID-19, are you willing to go to class for blended learning, meaning a combination of ONLINE plus FACE to FACE in-campus lessons and examinations?

1. If blended learning is the only option, are you going to enroll/teach classes?

m. If you have a choice and only if circumstances allow, please indicate your preference for the coming semesters. Choices are pure online, blended, pure face-to-face

A survey on Digital Learning Readiness (DLR) was designed to validate and identify the readiness of the university students to online learning[12]. This is imperative as bases for the effectiveness of any flexible learning platform to qualify the kind of learners to be put in such modality. Learning can be delivered effectively when students are aware of the use of tools and platform for learning, as well as student's technology readiness[13]. The DLR survey adapts the original work by Vicki Williams of Penn State University[14]. Listed below are the components of the survey and a sample question.

a. Self-Directedness (I am good at setting goals and deadlines for myself)

b. Learning Preferences (I can learn from things I hear, lectures, audio recording, or podcasts)

c. Study Habits (I am willing to spend 10-20 hours each week on an online course)

d. Technology Skills (I am comfortable conducting searches setting bookmarks, and downloading files)

e. Computer Equipment Capabilities (I have headphones or speakers and a microphone to use if a class has a video conference)

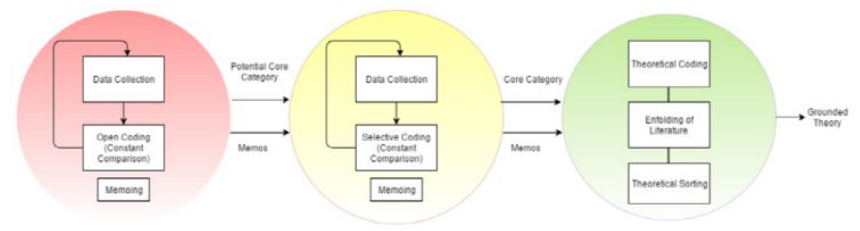

Figure 1: Research Method based on GTM

This research uses the Glaserian Grounded Theory Model (GTM), as shown in figure 1. GTM is a systematic generation of data theory through a collection of rigorous research procedures which lead to conceptual categories emerging. Such emerging concepts and definitions are interrelated as a theoretical interpretation of the actions(s), which continually addresses the participants' key concern in a concrete field. Fifteen faculty members from identified Higher Education Institutions who have online learning mechanisms were interviewed. Interviews were conducted via Zoom meetings, emails, and telephone calls. A thematic analysis was done to identify themes which are used in the design of the framework.

\section{RESULTS}

The survey and interviews provided bases for the Flexible Learning Framework Towards an Asynchronous Course Delivery.

\subsection{Center for Educational Technology}

The effectiveness and efficiency of a flexible learning adaption and implementation does not solely depend on the use of an LMS. There must be an office that caters to the needs of integrating technology and education in delivering flexible learning. This paper proposes the establishment of a CenteR for EducAtional TEchnology (CREATE) as the University Support Unit dedicated to supporting creative teaching and learning methods using the effective application of emerging technology in a versatile learning environment; This office is a representation of both technology and pedagogy skills, the Center for Educational Technology aims to lead, endorse and promote creative and practical ways of engaging student learning in the asynchronous course delivery (ACCORD) amidst converging and emerging digital technologies. The center must be under the direction of the highest academic officer, in cases of LUCs, the Vice President for Academic Affairs. The center is designed to contribute to all efforts towards academic excellence through enhancement of delivering instruction of the university in the appropriate design, development, and effective integration of educational media and emerging learning technologies. It will also be responsible for the training and mentoring faculty members continually in their ACCORD practices and needs, and the monitoring and reporting ACCORD implementation. The office shall compose of a director and a coordinator of each college. This office works with the Faculty Development Office of the LUC to design programs, interventions and solutions for the trainings as may be required and needed for the faculty, result in a Training Needs Analysis (TNA). 


\subsection{Faculty Development}

Today's educational landscape has put universities at the center of a disruptive cycle called information and communication technology (ICT) [15]. The proliferation of online learning has affected the structure and culture of education. The flexible learning modalities require the faculty to face new challenges[16][17] and to make new decisions in the areas of course management and design, delivery methods, communication platforms for students, development of an interactive learning environment, assessment and the use of emerging technologies. Training in new leadership skills in the classroom, collaborative learning, cooperative learning, one-to-one therapy, and the like is a priority. Learning and instructional materials in digital print shall also be provided for the teaching community.

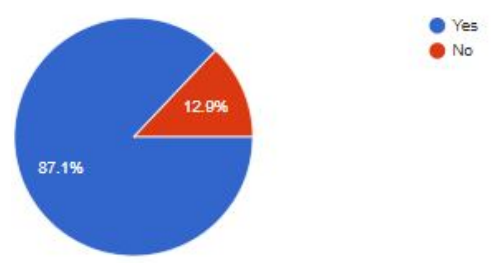

Figure 2: Faculty with Home Internet Access

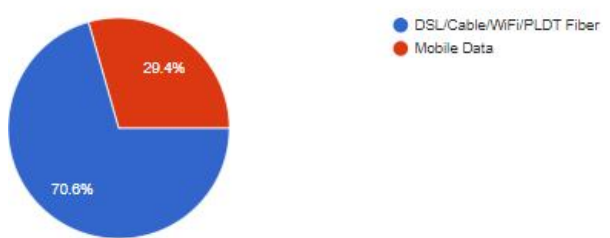

Figure 3: Faculty Internet Connection Type
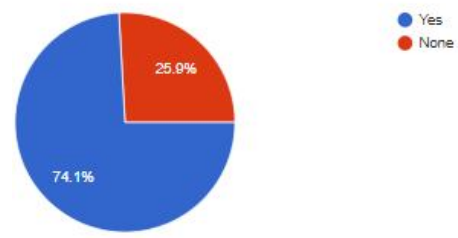

Figure 4: Faculty with Digital Learning Facilities at Home

The PNC Faculty statistics show that $87.1 \%$ percent of the faculty have reliable internet access at home (Fig:2), $29.4 \%$ rely on mobile data on their smartphones (Fig:3), and $74.1 \%$ have digital learning facilities at home(Fig:4). The faculty proficiency on applications relevant to flexible learning were also measured in the survey. The areas where faculty proficiency skills measured are search engine, email, office applications, cloud storage, online collaboration tools, video conference, chat applications, camera, photos, movie maker and audio recorder as reflected in Figure 5. Majority of the teaching workforce have Intermediate proficiency in the identified applications and tools.

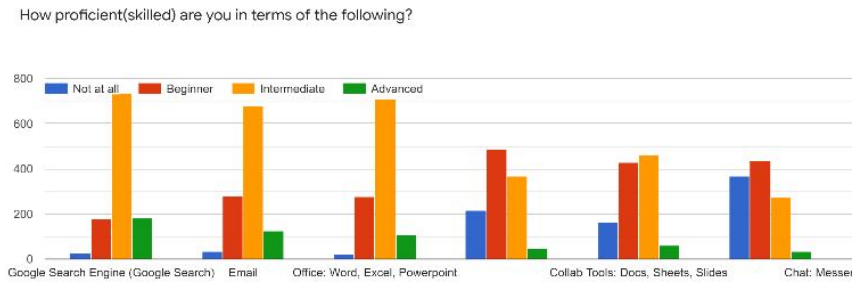

Figure 5: Faculty Applications Proficiency

The Faculty Capability Training (FCT) must be in place to ensure that the teaching workforce will become adaptive to ACCORD. Initially identified topics are: Learning Management Systems - Google Classroom/MS Teams, Courseware Development, New Learning: Principles and Patterns of Pedagogy, Exploring Emerging Technologies for Lifelong Learning and Success, Ubiquitous Learning and Instructional Technologies, Multimodal Literacies: Communication and Learning in the Era of Digital Media, Information \& Digital Literacy for University Success, and Best Practices in Digital Learning. Measures to enable digital capacity of the faculty is to strengthen the Universities partnership with Smart Communications Inc. (SMI) and provisions for an Internet Connectivity Allowance (ICA).

\subsection{Equipping the Students}

In the design of a flexible learning environment, it is imperative to look at the factors that affect such implementation such as the internet access of the students, and the availability of devices for online learning.
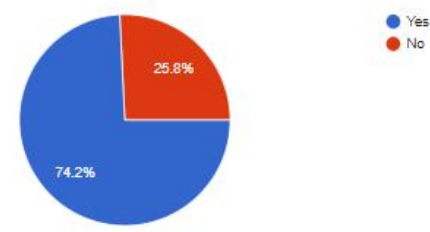

Figure 6: Student with Home Internet Access
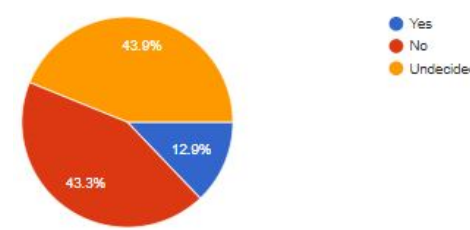

Figure 7: Willingness to buy WIFI gadget

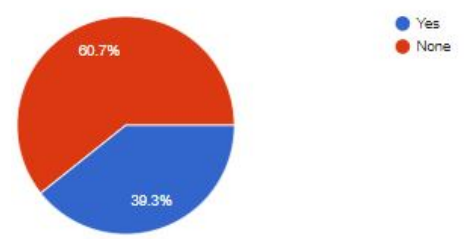

Figure 8: Available Home Facilities for Digital Learning 
Mideth B. Abisado et al., International Journal of Advanced Trends in Computer Science and Engineering, 9(1.3), 2020,413 - 421

The demographics of more than 3,500 PNC student population reveals that $25.8 \%$ of the students do not have Internet access at home, $43.3 \%$ are not willing or may not have the capacity to purchase a WFI device, and $40.1 \%$ have facilities at home for digital learning, as reflected in figures 6 to 8. Premises considered; the following are proposed actions to equip the students for flexible learning modality. In Cabuyao, Globe LTE Network Coverage is only in Mamatid Area[18], compared to Smart Communications that has wider coverage[19]. Considering the cellular network coverage and the University's partnership with Smart Comm. Inc., there is an opportunity that favors the students. The Digital Learning Initiative of SMI entails a discounted rate to registered PNC students of the regular data rates, as well as exclusive low-cost WIFI gadget prices.

The DLR Survey provided basis that $61.36 \%$ of the PNC students are ready for flexible learning delivery in terms of self-directedness towards learning, as reflected in Table 3 , and $62.1 \%$ of the learning preferences can be online, as reflected in Table 4.

Table 3: Measures of Self-Directedness

\begin{tabular}{|l|l|l|l|}
\hline Criteria & Agree & $\begin{array}{l}\text { Somewhat } \\
\text { Agree }\end{array}$ & Disagree \\
\hline $\begin{array}{l}\text { I am good at setting goals } \\
\text { and deadlines for myself. }\end{array}$ & $55 \%$ & $42.8 \%$ & 2.20 \\
\hline $\begin{array}{l}\text { I have a really good } \\
\text { reason for taking an } \\
\text { online course. }\end{array}$ & 38 & 52.3 & 9.70 \\
\hline $\begin{array}{l}\text { I finish the projects I } \\
\text { start. }\end{array}$ & $80.1 \%$ & 19.5 & 0.40 \\
\hline $\begin{array}{l}\text { I do not quit just because } \\
\text { things get difficult. }\end{array}$ & 76.6 & 22.6 & 0.80 \\
\hline $\begin{array}{l}\text { I can keep myself on } \\
\text { track and on time. }\end{array}$ & 57.1 & 40.6 & 2.30 \\
\hline Average & 61.36 & 35.56 & 3.08 \\
\hline
\end{tabular}

Table 4: Measure of Learning Preferences

\begin{tabular}{|l|l|l|l|}
\hline Criteria & Agree & $\begin{array}{l}\text { Somewhat } \\
\text { Agree }\end{array}$ & Disagree \\
\hline $\begin{array}{l}\text { I can learn from things I } \\
\text { hear, like lectures, audio } \\
\text { recordings or podcasts }\end{array}$ & 55.1 & 42 & 2.9 \\
\hline $\begin{array}{l}\text { I have to read something } \\
\text { to learn it best. }\end{array}$ & 76.8 & 22.3 & 0.9 \\
\hline $\begin{array}{l}\text { I have developed a good } \\
\text { way to solve problems I } \\
\text { run into. }\end{array}$ & 47.8 & 50.7 & 1.5 \\
\hline $\begin{array}{l}\text { I learn best by figuring } \\
\text { things out for myself }\end{array}$ & 56.1 & 41 & 2.9 \\
\hline $\begin{array}{l}\text { I like to learn in a group, } \\
\text { but I can learn on my own, } \\
\text { too }\end{array}$ & 74.7 & 24.5 & 0.8 \\
\hline Average & 62.1 & 36.1 & 1.8 \\
\hline
\end{tabular}

The results of the DLR considered, the students are concluded to become adaptive to a flexible learning environment.

\subsection{The Asynchronous Course Delivery Framework (ACCORD)}

In compliance with CHED Advisory No. 6 that mentions Stringent Social Distancing Measures (SSDM) adapting flexible learning and other alternative modes of delivery instead of in-campus learning[3]. Current online courses have been prevalent today. Coursera, Udemy and Edx are included in the top providers for a student's access to online course content and certificate[20]. Full-online learning has been available for the longest time. The ECQ promoted this opportunity to the Philippine setting[21], and the marginalized students will not be left behind. The great digital divide is still present, thus the measures for providing access and opportunities to the marginalized students. A survey on student Internet accessibility is imperative to account for capabilities for new learning modes. The PNC Student Accessibility Survey reveals that $25.8 \%$ of students do not have access to a stable and reliable internet connection for flexible learning. This is where the LUC brand of flexible learning comes to place.

ACCORD is a framework of flexible learning that will aptly advance the LUCs' brand of higher education. Asynchronous learning refers to providing training that does not require learners and facilitators to be simultaneously online for learning to take place. Tools used by course designers to integrate engagement include quizzes, assessments, order or rate controls, additional dimension through video, and reflective opportunities. [22][23]. The learning styles of each student can be assessed as data are collected using an LMS[24]. It is composed of two modalities: Full online (FILE) and blended learning (BEAR). As asynchronous learning becomes the 2020 norm throughout Philippine academia, changes are taking place in campus information systems. The University Library is expected to adapt to this type of modality[25].

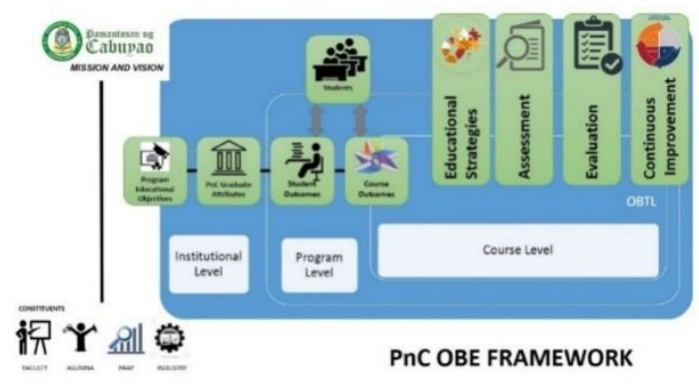

Figure 9: OBE Framework 
ACCORD will comply with CHED CMO No. 46, S. 2012 stating the implementation of OBE in Philippine universities and colleges when proposed changes is implemented. ACCORD proposes to revise the PNC current grading system to an Outcomes-Based course grading system to become OBE compliant[26]. The current grading system is not compliant to the PNC OBE[27] Framework reflected in Figure 9. Outcomes-Based Education measures the Course Outcomes specified in the Outcomes-Based Teaching and Learning Plans (OBTLP), also known as the course syllabus[27]. The components of the current system is boxed in the idea that all courses[28][27][29], regardless of its nature, is measured the same way, assessment activities, and weights its weights

The proposed grading system shall use a standard Assessment Tasks, relative to the course and agreed upon by the course cluster, approved by the Continuous Quality Improvement (CQI) committee of the college. These measures are important in maintaining quality standards in an HEI[30]. The PNC-IMS shall adapt to this, requiring only the Major Grading Terms as input to the system, encoded by the faculty. The grading system is progressive. The new grading system brief shall be drafted for the Board of Regents approval.

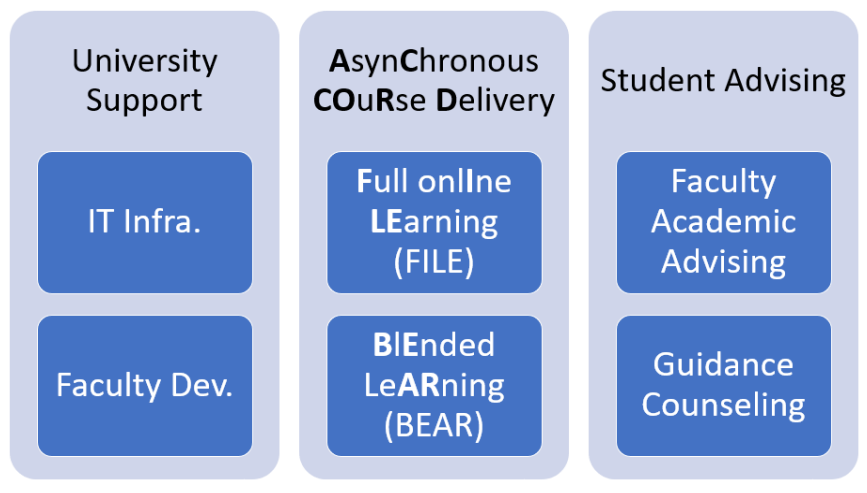

Figure 10: ACCORD Framework

The ACCORD framework (see Figure 10) works on the premise that a learning environment can be conceptualized by four different components that each embedded different perspectives on quality: Learner, Learning Environment, Goal and Intention, and Topic and Content[4]. The University support in terms of providing appropriate IT Infrastructure and comprehensive faculty development program is a premise to its success in implementation. With ACCORD environment, academic advising and faculty consultation plays an important role to help and assist failure-prone students with low optimism. The guidance office therefore should be able to design measures for motivation treatments [31] to enhance goal engagement that can improve academic outcomes for the students.

The LEAP component of the framework refers to Learning Packets. LEAP contains, but not limited to, OBTLP, Course Policies, Required Readings list, Lessons (rich and low media), and Course Assessments(such as but not limited to,
Experiment, Quizzes, Assignments, Case Study/Analysis, Machine Problems, Design Problems). It shall be used in new methods[32] that will ensure the health, safety, accessibility, and convenience of our students when we open our new academic year. It will be available to our students in print and digital, rich media and low media versions.

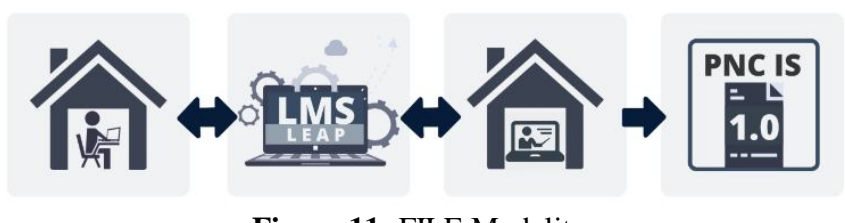

Figure 11: FILE Modality

Full onlIne LEarning (FILE), as reflected in Figure 10, is a modality that uses full online learning. There will be no face to face interaction between the teacher and the student[33]. The students will not have a prolonged online video class with their professors, instead, LEAP is distributed to the students using minimal $\mathrm{MB}$ for downloading, thus only requiring minimal bandwidth. There are measures in place for administration and salary purposes that make sure professors have close coordination with the students to make sure no-one is left behind. LEAP will be provided to the students after completion of enrollment or registration. The distribution of LEAP can be done in campus, or with the help of the LGU-Barangay Units. FILE does not encourage students to go out to public places such as internet cafes for prolonged periods. This is the reason why LEAP is downloadable with individual studies. The FILE mode is proposed to waive all laboratory fees of students since no computer laboratory will be used in the delivery.

The components include the adapted Learning Management System (LMS) where the LEAP is deployed. The LMS serves as the major platform for the interaction of the student and the course professor. The deployment and submission of the different course assessment tasks shall be in the LMS. The course professor monitors student progress and must give timely feedback. FILE will follow the course grading system, the faculty will upload the class grade to the PNCIS during grade submission periods: Prelim, Midterm, and Finals. FILE follows the Work-From-Home (WFH) model, the faculty accomplishes the WFH-Course Delivery Monitoring attached in Appendix A. An able faculty assigned a FILE section shall be given full credit unit as teaching load subject to CHED, IATF, CSC, and DBM rules and regulations.

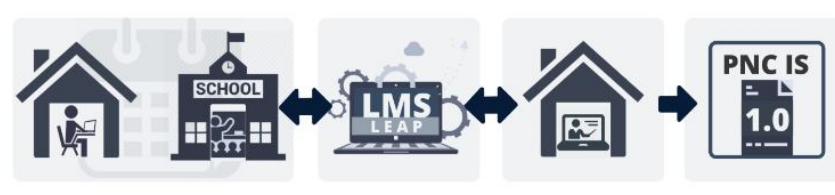

Figure 12: BEAR Modality 
BlEnded LeARning (BEAR) as shown in Figure 11, is a combination of online and face-to-face in campus meetings modality. Blended learning is an new form of education prepared by integrating the positive aspects of various learning methods to provide great convenience. This approach is aimed at achieving its goal by combining face-to - face interaction in traditional learning, time , place, and material wealth through web-based learning [34]. Blended learning has become the well-versed educational program amongst HEIs in these times of the COVID 19 pandemic. This approach gives the ability to be able to create flipped activities in which learners can complete pre and post-lesson to gain an understanding of topics. BEAR modality implements the OBTLP with specified in-campus class face-to-face meetings, however, a high percentage of the course meetings is scheduled on-line. These are very beneficial as they allow time in traditional classrooms to focus on extending the learner's knowledge and to support them in reaching the higher levels of learning[35]. BEAR follows the Semi-Work-From-Home (WFH) model, the faculty accomplishes the WFH-Course Delivery Monitoring attached in Appendix A. An able faculty assigned a BEAR section shall be given full credit unit as teaching load subject to CHED, IATF, CSC, and DBM rules and regulations. FILE and BEAR implement measures and cautions the faculty to avoid over-assigning or under-assigning of online activities. Both modalities follow the standard OBTLP, as designed by the course cluster, evaluated to be compliant to the Program CQI Plan college CQI and approved by the College Dean.

While traditionalist and non-progressive thinkers will list the negative impacts of the flexible learning environment such as diminishing the interest of learners, reduction of the communication between the lecturer and students, the need for good self-discipline, and responsibility to the learning process, it is worth considering that these studies are only a few. In a study, when the course results were evaluated using the full sample of students, no effects were found on outcomes from previous experience versus none[36]. It ensures that, irrespective of previous experience, the students are considered to conform to ACCORD.

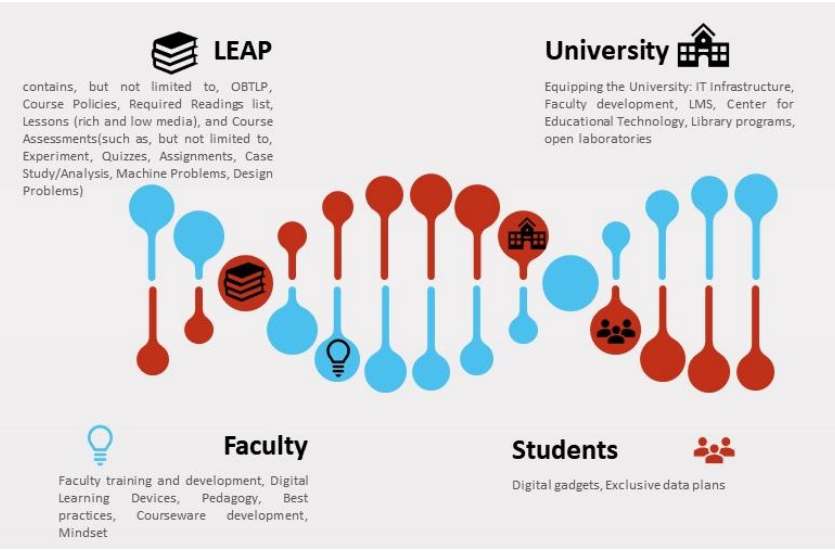

Figure 13: ACCORD DNA
Student engagement, faculty engagement, usage of online course materials is promoted as being key resources for success in the course, and the implementation of ACCORD. The ACCORD DNA is provided in this paper, as reflected in Figure 13, the development of LEAP, the creation of a center for technology education, and equipping the university, faculty, and students.

\section{CONCLUSIONS AND FUTURE DIRECTIONS}

The Asynchronous Course Delivery Framework for a LUCs provides a solution to mitigate the spread of the COVID 19 pandemic, as well as compliant to the WHO, DOH, CHED and IATF standards. It is important that all framework components are covered. A gradual implementation may be done. A digital capability survey must be done to identify actions to equip all stakeholders such as the administrators, faculty, and students. The Asynchronous Course Delivery adheres to flexible learning. When the students do not have any access to the Internet, different ways can be done to deliver the LEAP, with the help of the Barangay Unit Correspondence Style, is a method that can be optimized. Future direction of this study include analysis of the actual implementation and designing OBEdized recording of course assessments to meet the program outcomes. Identification of the adaptability of students and faculty members are also in the pipeline on the totality of this study.

\section{ACKNOWLEDGEMENT}

The paper recognizes faculty members from the National University, Mapua University, Philippine University of Technology, Philippine Institute of Technology, Santo Tomas University, Far Eastern University, Unibersidad de Manila, Bicol University, and Pamantasan ng Lungsod ng Muntinlupa, and Pamantasan ng Cabuyao faculty and students who participated as study respondents.

\section{REFERENCES}

1. L. Benade, "Flexible Learning Spaces: Inclusive by Design," New Zealand Journal of Educational Studies, 2019. [Online]. Available:

https://www.researchgate.net/publication/34043929

2_Flexible_Learning_Environments_SITE_poster1.

[Accessed: 25-Apr-2020]. https://doi.org/10.1007/s40841-019-00127-2

2. J. R. Hill, "Flexible learning environments: Leveraging the affordances of flexible delivery and flexible learning," Innovative Higher Education, vol. 31, no. 3. pp. 187-197, Oct-2006. https://doi.org/10.1007/s10755-006-9016-6

3. Commission on Higher Education [CHED], "CHED COVID Advisory No. 6,” vol. 2020, no. AprilL 13, 
2020, pp. 1-10, 2020.

4. R. Kraleva, M. Sabani, and V. Kralev, "An analysis of some learning management systems," Int. J. Adv. Sci. Eng. Inf. Technol., vol. 9, no. 4, pp. 1190-1198, 2019.

https://doi.org/10.18517/ijaseit.9.4.9437

5. D. Turnbull, R. Chugh, and J. Luck, "Learning Management Systems: An Overview," Springer Encyclopedia of Education and Information Technologies, 2019. [Online]. Available: https://www.researchgate.net/publication/33546392 0_Learning_Management_Systems_An_Overview. [Accessed: 21-Apr-2020].

6. D. A. Corpus, "Learning Management System to Enhance the Research Capability of Public School Teachers," Int. J. Adv. Trends Comput. Sci. Eng., vol. 9, no. 1.2, pp. 127-131, 2020.

https://doi.org/10.30534/ijatcse/2020/1991.22020

7. Henderi, QurotulAini, A. DwiSrenggini, and AlfiahKhoirunisa, "Rule Based Expert System for Supporting Assessment of Learning Outcomes," Int. J. Adv. Trends Comput. Sci. Eng., vol. 9, pp. 267-271, 2020.

https://doi.org/10.30534/ijatcse/2020/3991.22020

8. V. Juričić, M. Radošević, and A. Pongrac Pavlina, "Characteristics of Modern Learning Management Systems," in 14th International Technology, Education and Development Conference 2020 Proceedings, 2020, vol. 1, pp. 7685-7693.

9. G. Ng, "Adapting to Learning Management System," in Conference: IST Brown Bag Session, 2017.

10. F. B. Lavoie and P. Proulx, "A Learning Management System for Flipped Courses," in Conference: ICDTE 2019: 2019 The 3rd International Conference on Digital Technology in Education.

11. I. Al-Kindi and Z. Al-Khanjari, "The Smart Learning Management System (SLMS)," in Free and Open Source Software Conference(FOSS2019-OMAN).

12. T. J. B. Blayone, "Reexamining Digital-Learning Readiness in Higher Education: Positioning Digital Competencies as Key Factors and a Profile Application as a Readiness Tool," Int. J. E-Learning, vol. 17, pp. 425-451, 2018.

13. S. Geng, K. M. Y. Law, and B. Niu, "Investigating self-directed learning and technology readiness in blending learning environment," Int. J. Educ. Technol. High. Educ., vol. 16, no. 1, p. 17, Dec. 2019.

14. V. Williams, "Online Learning Readiness Questionnaire." [Online]. Available: https://www.fhu.edu/tutorials/student/online-learnin g-readiness-assessment. [Accessed: 01-Mar-2020].

15. R. vanOostveen, F. Desjardins, and S. Bullock, "Professional development learning environments (PDLEs) embedded in a collaborative online learning environment (COLE): Moving towards a new conception of online professional learning," Educ. Inf. Technol., vol. 24, no. 2, pp. 1863-1900, Mar. 2019. https://doi.org/10.1007/s10639-018-9686-6

16. B. Maziane, M. Bassiri, S. Benmokhtar, and S. Belaaouad, "Engineering analysis of teaching practices and learning strategies guided by the principles of Cognitive Psychology and Information technology," Int. J. Adv. Trends Comput. Sci. Eng., vol. 9, pp. 212-217, 2020.

17. Y. Q. Bongalos et al., "University teachers' experiences in courseware development," Exp. Coursew. Dev. J. Educ. Technol. Br. J. Educ. Technol., vol. 37, no. 5, pp. 695-704, 2006.

18. Globe Telecom., "Globe LTE Coverage Areas." [Online].

Available: https://www.globe.com.ph/help/mobile-internet/lte/ coverage-areas.html. [Accessed: 19-Apr-2020].

19. Smart Comm. Inc., "Network Finder - Smart Communications, Inc." [Online]. Available: http://apps.smart.com.ph/network. [Accessed: 19-Apr-2020].

20. M. Abisado, B. Gerardo, and A. C. Fajardo, “ $\square$," in Towards Keystroke Analysis using Neural Network for Multi-Factor Authentication of Learner Recognition in On-Line Examination, 2017.

21. A. B. de Guzman, "The dynamics of educational reforms in the Philippine basic and higher education sectors," Asia Pacific Educ. Rev., vol. 4, no. 1, pp. 39-50, Feb. 2003.

22. S. Sana, C. Adhikary, and K. N. Chattopadhyay, "Synchronous Vis-a-Vis Asynchronous Learning: A Blended Approach." [Online]. Available: https://www.researchgate.net/publication/33855540 6_Synchronous_Vis-a-Vis_Asynchronous_Learning _A_Blended_Approach. [Accessed: 20-Apr-2020].

23. E. Biech, "Online Asynchronous Learning," 2015. [Online]. Available: https://www.researchgate.net/publication/31960956 4_Online_Asynchronous_Learning. [Accessed: 29-Mar-2020].

24. K. D. J. Agreda, M. I. P. D. L. Trinos, and M. C. F. Francisco, "Development of E-Modality: A Learning Style Assessment Tool," Int. J. Adv. Trends Comput. Sci. Eng., vol. 9, pp. 230-235, 2020. https://doi.org/10.30534/ijatcse/2020/3491.22020 
25. J. Eustis and G. McMillan, "Libraries Address The Challenges Of Asynchronous Learning," Online Learn., vol. 2, no. 1, Mar. 2019.

26. Commission on Higher Education [CHED], "Policy-Standard to Enhance Quality Assurance (QA) in Philippine Higher Education through Outcomes-Based and Typology-Based QA.” pp. 1-36, 2012.

27. William G. Spady, Critical Issues and Answers Outcome-Based Education, no. Lmi. 1994.

28. CEI, "OBE Principles and Process," Center for Education Innovation. [Online]. Available: http://cei.ust.hk/teaching-resources/outcome-basededucation/institutional-resources/obe-principles-and -process. [Accessed: 27-Mar-2020].

29. J. Macayan, "Implementing Outcome-Based Education (OBE) Framework: Implications for Assessment of Students' Performance," Educational Measurement and Evaluation Review Vol 8, Issue 1, 2017. [Online]. Available:

https://www.researchgate.net/publication/32179705 0_Implementing_Outcome-Based_Education_OBE _Framework_Implications_for_Assessment_of_Stu dents'_Performance. [Accessed: 03-Apr-2020].

30. A. B. de Guzman and J. R. Torres, "The University of Santo Tomas viewed from the lens of total quality management: Implications to total quality education," Asia Pacific Educ. Rev., vol. 5, no. 1, pp. 88-99, Feb. 2004.

31. J. M. Hamm, R. P. Perry, J. G. Chipperfield, P. C. Parker, and J. Heckhausen, "A motivation treatment to enhance goal engagement in online learning environments: Assisting failure-prone college students with low optimism.," Motiv. Sci., vol. 5, no. 2, pp. 116-134, Jun. 2019. https://doi.org/10.1037/mot0000107

32. J. Wong, M. Baars, D. Davis, T. Van Der Zee, G.-J. Houben, and F. Paas, "Supporting Self-Regulated Learning in Online Learning Environments and MOOCs: A Systematic Review," Int. J. Human-Computer Interact., vol. 35, no. 4-5, pp. 356-373, Mar. 2019.

33. S. T. M. Sithole and S. Akpinar, "Transition from classroom to Blended Online Asynchronous Learning," RMIT Accounting Educators' Conference. $\quad$ [Online]. Available: https://www.researchgate.net/publication/33018005 7_Transition_from_classroom_to_Blended_Online_ Asynchronous_Learning. [Accessed: 29-Mar-2020].

34. C. A. Bai, "A Study on OUtcomes of Blended Learning," in IUT Journal of Adavance Research and Development, 2020, no. January.
35. M. Fazal, B. Panzano, K. LukMelanie, and B. Bryant, "Measuring Blended Learning Effectiveness," 4th International Technology, Education and Development Conference, 2020. [Online]. Available: https://www.researchgate.net/publication/34012331 4_MEASURING_BLENDED_LEARNING_EFFE CTIVENESS. [Accessed: 19-Apr-2020].

36. C. J. Asarta and J. R. Schmidt, "The effects of online and blended experience on outcomes in a blended learning environment," Internet High. Educ., vol. 44, no. September 2018, p. 100708, 2020.

https://doi.org/10.1016/j.iheduc.2019.100708 